\title{
TEACHING WRITING USING THINK-PAIR-SHARE VIEWED FROM STUDENTS' LEVEL OF RISK-TAKING
}

\author{
Ningtyas Orilina Argawati \\ English Department of STKIP Siliwangi \\ E-mail: tyas.orilina@yahoo.com \\ Lilis Suryani \\ English Department of STKIP Siliwangi \\ E-mail: suryani.lies3@gmail.com
}

\begin{abstract}
APA Citation: Argawati, N. O., \& Suryani, L. (2017). Teaching writing using think-pair-share viewed from students' level of risk taking. English Review: Journal of English Education, 6(1), 109-116. DOI: 10.25134/erjee.v6i1.776.
\end{abstract}

Published: 01-12-2017

\begin{abstract}
Writing is considered as the most difficult skill to master compared with the other skills because it involves many language elements such as content, organization, vocabulary, grammar and mechanics. The research examines the effect of two independent variables (Think-Pair-Share and Direct instruction method) on dependent variable (Writing Descriptive skill). The samples were class A1 2016 as the experimental class and A3 2016 as the control class. Each class consisted of 32 students. The instruments used covered the risk-taking's questionnaire and writing test. Before applying the questionnaire of risk-taking, it was tried out to class A2 2016 to find out the validity and the reliability of the instrument. Meanwhile, before conducting the writing test, it needs to test the readability of the writing instruction. The treatment was conducted in eight meetings, and the 9th meeting was allocated for the post-test. The data were then analyzed using ANOVA and Tukey test. From the analysis, it reveals that: (1) Think-Pair-Share is significantly different from direct instruction method to teach writing; (2) the students with high level of risk-taking have better writing than those with low level of risk-taking; and (3) there is an interaction between teaching methods and the students' level of risk-taking. Even though Think-Pair-Share is effective to teach writing, teachers must consider about the students' condition, in this case their level of risk-taking.
\end{abstract}

Keywords: Think-Pair-Share, Direct instruction method, Writing descriptive text, Risk-Taking

\section{INTRODUCTION}

Writing takes an important role in the students' process of learning English. It is one of the most visible learning products, and becomes one of the criteria for passing the grade in University. Besides, this mastery of writing skill will affect their thesis writing on the last semester as their final project. Through writing, students can express feeling, describe something, discuss an idea, present a point of view, share experience they have in the form of written product. It is in line with what had been stated by Caroline (2003, p. 4) that writing is producing something in written form so that people can read, perform and use it.

Writing plays two distinct but complementary roles. First, it is a skill that draws on the use of strategies (such as planning, evaluating, and revising text) to accomplish a variety of goals, such as writing a report or expressing an opinion with the support of evidence. Second, writing is a means of extending and deepening student's knowledge; it acts as a tool for learning subject matter (Graham \& Perrin, 2007, p. 9).

In learning writing text, students will learn many kinds of texts such as report, descriptive, narrative, analytical exposition, recount, etc. In this research, the researchers only focus on the material based on the syllabus; it is writing descriptive text. Writing discriptive text can activate the students on how they describe something or someone with their capability of 
constructing their idea into appropriate sentence and in correct order. It also helps them to improve their ability to words to create a picture, establishing mood and point of view by using sensory details. Many adjectives involved in descriptive writing to explain subject clearly.

Due to the importance of writing, teacher has to find a suitable and effective method to improve students' writing skill. One of the methods that can be applied is Think-pairshare. Think-Pair-Share is a strategy designed and developed by Lyman and associates to encourage student classroom participation (2005). He stated that Think-pair-share (TPS) is a "multi mode" strategy developed to encourage students' participation in the classroom activities. There are several benefits of applying TPS method to teach writing according to Lyman (2005), they are: 1) it can build positive interdependence; 2 ) it can build individual accountability; (3) it gives opportunity to the students to think together; (4) it increases their sense of involvement; (5) it benefits students in the areas of peer acceptance, peer support, academic achievement, self-esteem and interest in other students; 6) It can promote the effectiveness of team work. Besides having advantages, applying TPS also has some disadvantages, they are: (1) failure to get along, 2) Noise, and 3) Absences. Here, think-Pair-Share helps students develop conceptual understanding of a topic because they discuss it with their friend in pair. It makes them feel free to discuss about everything they want relating to describing someone or something. By doing that activity, their ability to filter information, write down conclusion and consider point of view will be developed.

However, many teachers seem to prefer teaching writing using direct instruction method to teaching writing using Think-PairShare. Arends (1997, p. 66) argues that direct instruction method was specifically designed to promote student learning of procedural knowledge. Direct instruction method is a teaching method developed by Engelman (Binder \& Watkin, 1990, p. 7). It is a teaching bmethod in which the teacher transmits information directly to the students, the lesson are goal-oriented and structured by the teacher. Further, Alan (2003, p. 11) states that direct instruction method or teacher centered instruction generally put in "teacher-centeredinstruction". The teacher role is that of a knowledge expert whose major job is to pass knowledge directly to students. The students' job is to absorb or otherwise assimilate the new knowledge. Joyce, Weil and Calhoun (2000, p. 337) states that DIM has its theoretical origins in the behavioral family particularly in the thinking of training and behavioral psychologist. Briefly, direct instruction method is a teacher-centered method which is used to help students in learning a basic skill and knowledge and can be taught in step by step fashion.

Another factor affecting writing skill mastery is willingness of the students to make a decision involving something new and different without putting the primary focus on success or failure (Bem, 1971 in Bang, 1999, p. 13). It can be defined as risk-taking. According to Brown (2001, p. 149), risktaking is an important characteristic of successful learning of a second language which refers to the learner's ability to gamble a bit, to be willing to try out hunches about the language, and take the risk of being wrong.

Rubin (1975, pp. 43-48) and Beebe (1983, p. 46) in Luft (2007, p. 2) identifies four characteristics and behaviors related to risktaking: 1) being willing to appear foolish in order to communicate and get the message across; 2) using the language when not required to do so; 3) being comfortable with uncertainty and willing to try out guesses; and 4) being willing to make mistake in order to learn and communicate

Risk-taking can influence the use of TPS (Think-Pair-Share) method where students who have high risk-taking will have good ability in their work on pair. They can develop themselves freely about what they want to write. It will impact their words' production and make them increase their ability to write something. As result, they will have good 
achievement than being taught using direct instruction method. On the other hand, students who have low risk-taking will feel losing guide and cannot do anything. It is because they used to be passive. Therefore, they will get better achievement if they are taught using direct instruction method.

Based on the background above, the researcher formulates the problems of this study as follows: 1) Is TPS more effective than DIM to teach writing?; 2) Do students with high level of risk-taking have better writing skill than those who have low level of risktaking?; 3) Is there any interaction between teaching methods and level of risk-taking on teaching writing for the second grade students? Then, the hypotheses are formulated as follows: (1) using TPS is more effective than DIM to teach writing; (2) the students with high risk-taking have better writing skill than the students with low risk-taking; (3) there is interaction effect between teaching methods and the students' level of risk-taking to teach writing for second grade students of STKIP Siliwangi.

\section{METHOD}

The research was conducted on the second semester students of STKIP Siliwangi. It covers the composing proposal, conducting research in the school, collecting the data, analyzing the data, and reporting. This research uses experimental method. The experiment examines the effect of two independent variables on a dependent variable. Independent variables are the teaching methods and Risk-taking while the dependent variable is writing skill. The population in this research is the second semester student of STKIP Siliwangi. The researchers use cluster random sampling in this study. To determine which one is experimental and control group, the researcher uses lottery to draw the class.

There are two kinds of techniques used to collect the data. They are writing test and questionnaire of risk-taking. Writing test is used to collect the data of students' writing. The writing test is used to know the students' writing skill after treatment. For this writing test, the researchers assessed the readability of the test instruction which informs whether the test instruction is appropriately readable for the students. Meanwhile, to know the students' level of risk-taking, the researcher distributed the questionnaire to the students. Before being applied, the questionnaire was tried out to analyze its validity and reliability.

The techniques for analyzing the data of this study are descriptive and inferential statistics. The descriptive statistics were used to know the mean, median, mode, standard deviation, histogram, and polygon of students' score of writing. To know the normality and the homogeneity of the data, the writer uses normality and homogeneity test. The normality and homogeneity tests were done before testing the hypothesis. Inferential analysis used is multifactor analysis of variance (ANOVA $2 \times 2$ ). It is used to test the hypothesis. $\mathrm{H}_{0}$ is rejected if $\mathrm{F}_{0}$ is higher than Ft. If $\mathrm{H}_{0}$ is rejected, the analysis is continued to know which group is better using Tukey test.

\section{RESULTS AND DISCUSSION}

After conducting the treatment and doing the test, the researchers conducted normality test to know whether or not the data were in normal distribution. The result of normality test is displayed in table 1 below.

Table 1 . The sum of normality test

\begin{tabular}{rlrrrl}
\hline No & Group & \multicolumn{1}{c}{ Lo } & Lt & \multicolumn{1}{l}{ Alpha } & Status \\
\hline 1 & A1 & 0.0944 & 0.156624 & 0.05 & Normal \\
2 & A2 & 0.10485 & 0.156624 & 0.05 & Normal \\
3 & B1 & 0.0859 & 0.156624 & 0.05 & Normal \\
4 & B2 & 0.0859 & 0.156624 & 0.05 & Normal \\
5 & A1B1 & 0.1363 & 0.213 & 0.05 & Normal \\
\hline
\end{tabular}


Ningtyas Orilina Argawati \& Lilis Suryani

Teaching writing using think-pair-share viewed from students' level of risk-taking

\begin{tabular}{llllll}
\hline 6 & A2B1 & 0.1648 & 0.213 & 0.05 & Normal \\
7 & A1B2 & 0.0968 & 0.213 & 0.05 & Normal \\
8 & A2B2 & 0.1461 & 0.213 & 0.05 & Normal \\
\hline
\end{tabular}

Based on the table above, all the highest value of Lo is lower than $\mathrm{Lt}$ or $(\mathrm{Lo}<\mathrm{Lt})$ at the significance level $\alpha=0.05$, it can be concluded that the data are in normal distribution.
Then, based on the result of the calculation,

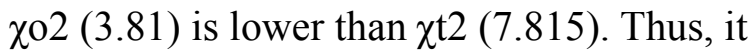
can be concluded that the data are homogenous.

Table 2. Homogeneity test

\begin{tabular}{rrrlrr}
\hline Sample & Df & 1/df & si2 & log si2 & (df)log si2 \\
\hline $\mathbf{1}$ & 15 & 0.07 & 25.9 & 1.41 & 21.20788 \\
$\mathbf{2}$ & 15 & 0.07 & 41.8 & 1.62 & 24.32219 \\
$\mathbf{3}$ & 15 & 0.07 & 54.6 & 1.74 & 26.05789 \\
$\mathbf{4}$ & 15 & 0.07 & 22.6 & 1.35 & 20.31043 \\
& 60 & & & & 91.89838 \\
\hline
\end{tabular}

Table 3. The mean scores of the Cells

\begin{tabular}{llll}
\hline & A1 & A2 & \\
\hline B1 & 79.75 & 68.75 & 74.25 \\
B2 & 68.3125 & 73.9378 & 70.625 \\
& 74.03125 & 70.8438 & \\
\hline
\end{tabular}

Table 4. The summary of analysis of variance $2 \times 2$

\begin{tabular}{llllll}
\hline Source of variance & SS & Df & MS & Fo & Ft \\
\hline Between columns & 162.5625 & 1 & 162.5625 & 4.485772 & 4 \\
Between rows & 210.25 & 1 & 210.25 & 5.801667 & \\
Column by rows & 976.5625 & 1 & 976.5625 & 26.9474 & \\
Between group & 1349.375 & 3 & 449.7917 & & \\
Within group & 2174.375 & 60 & $\mathbf{3 6 . 2 3 9 5 8}$ & & \\
Total & 3523.75 & 63 & & & \\
\hline
\end{tabular}

Based on the data above, it can be concluded that: 1) Since Fo between columns (4.49) is higher than Ft (4.00) at the level of significant $\alpha=0.05$ or $(4.49>4.00)$, Ho is rejected and the difference between columns is significant. It means that here is a significant difference between students who are taught using TPS and those who are taught using DIM in their writing skill. The mean score of the students who are taught using TPS (74.03) is higher than those who are taught using DIM (70.84). Therefore, it can be concluded that TPS is more effective to teach writing; 2) Since Fo between rows (5.80) is higher than $\mathrm{Ft}$ (4.00) at the level of significant $\alpha=0.05$ or $(5.80>$ 4.00), Ho is rejected and the difference between rows is significant meaning that there is a significant difference between students with high level Risk-Taking and those with low level Risk-Taking in their writing skill. The mean score of the students with high level Risk-Taking (74.25) is higher than those with low level Risk-Taking (70.63). Therefore, it can be concluded that the students with high level Risk-Taking have better writing skill than those with low level Risk-Taking; 3) Because Fo columns by rows (26.95) is higher than $\mathrm{Ft}$ (4.00) at the level of significant $\alpha=$ 0.05 or $(26.95>4.00)$, Ho is rejected and there is the interaction between teaching methods and the students' level of Risk-Taking to teach writing. Therefore, it can be concluded that the effect of teaching methods to teach writing depends on the students' level of Risk-Taking. 
Table 6. The sum of Tukey test

\begin{tabular}{ccccccc}
\hline No & Data & Sample & $\mathbf{q}_{\mathbf{o}}$ & $\mathbf{q}_{\mathbf{t}}$ & $\boldsymbol{\alpha}$ & Status \\
\hline 1 & $\mathrm{~A}_{1}$ and $\mathrm{A}_{2}$ & 64 & 2.995254 & 2.89 & 0.05 & Significant \\
2 & $\mathrm{~B}_{1}$ and $\mathrm{B}_{2}$ & 64 & 3.406367 & 2.89 & 0.05 & Significant \\
3 & $\mathrm{~A}_{1} \mathrm{~B}_{1}$ and $\mathrm{A}_{2} \mathrm{~B}_{1}$ & 32 & 7.309052 & 3.00 & 0.05 & Significant \\
4 & $\mathrm{~A}_{1} \mathrm{~B}_{2}$ and $\mathrm{A}_{2} \mathrm{~B}_{2}$ & 32 & 3.073124 & 3.00 & 0.05 & Significant \\
\hline
\end{tabular}

Based on the table above, it can be concluded that: 1) Since qo between A1 and A2 (2.99) is higher than qt (2.89) at the level of significant $\alpha=0.05$, it means that applying TPS is significantly different from DIM to teach writing. The mean score of A1 (74.03) is higher than A2 (70.84). Therefore, it can be concluded that TPS is more effective than DIM to teach writing skill; 2) Since qo between B1 and B2 (3.41) is higher than qt (2.89) at the level of significant $\alpha=0.05$, the students with high level Risk-Taking are significantly different from those with low level Risk-Taking in their writing skill. The mean score of B1 (74.25) is higher than B2 (70.63). Therefore, it can be concluded that the students with high level of Risk-Taking have better writing skill than those with low level of Risk-Taking; 3) Because qo between A1B1 and A2B1 (7.31) is higher than qt (3.00) at the level of significant $\alpha=0.05$, TPS differs significantly from Direct instruction method to teach writing for students with high level of risk-taking. Then, the mean score of A1B1 (79.75) is higher than A2B1 (68.75).

Therefore, it can be concluded that TPS is more effective than DIM to teach writing for the students with high level of risk-taking; 4) Since qo between A2B2 and A1B2 (3.07) is higher than qt (3.00) at the level of significant $\alpha=0.05$, TPS differs significantly from Direct instruction method to teach writing for the students with low level of risk-taking. The mean score of A2B2 (72.94) is higher than A1B2 (68.31). Therefore, it can be concluded that Direct instruction method id more effective to teach writing than TPS for the students with low level of risk-taking.

Based on the findings of the study, it can be concluded that 1) TPS is more effective than DIM to teach writing, 2) Students with high risk-taking have better writing skill than those who have low risk-taking, and 3) There is an interaction between teaching methods and level of risk-taking. Firstly, teaching writing skill using TPS makes students learn actively and successfully in writing class. Think-Pair-Share helps students develop conceptual understanding of a topic because they discuss it with their friends in pair. It makes them feel free to talk about everything they want deal with the topic. By doing that activity their ability to filter information, draw conclusion and consider point of view will be developed. Besides, setting the students in pair gives more opportunities to the students on exploring themselves. They will be encouraged to share something deeper and more detail. The more they share and talk about something, the more they build their confidence to write. Think-Pair-Share gives them opportunity not only to improve their writing skill but also to build their social relation with other students during the activity. On the other hand, teaching writing using Direct Instruction method is different with teaching writing using TPS since DIM does not involve group work. The general goal of the DIM is to provide learners with a practically useful knowledge of language. It includes lecturing, didactic questioning, and explicit teaching, practicing and drilling, and demonstrating. It is highly structured and teacher directed. The teacher control occurs when the teacher selects and directs the learning tasks. In this case, the students tend to be passive and dependent. As the result, teaching writing using TPS method is more effective than DIM.

Secondly, one of the factors affecting writing skill mastery is willingness of the students to make a decision involving 
something new and different without putting the primary focus on success or failure (Bem, 1971 in Bang, 1999, p. 13). It can be defined as risk-taking. Rubin (1975, pp. 43-48) and Beebe (1983, p. 46) in Luft (2007, p. 2) identifies four characteristics and behaviors related to risk-taking: 1) being willing to appear foolish in order to communicate and get the message across; 2) using the language when not required to do so; 3 ) being comfortable with uncertainty and willing to try out guesses; and 4) being willing to make mistake in order to learn and communicate. Students who have those characteristics are considered as high risk-taking students. In terms of writing, students with high risktaking can develop themselves freely about what they want to write. It will impact their words' production and make them increase their ability to write. The students who have high risk-taking will have a better attitude in following the teaching and learning process since risk-taking increases proficiency in the target language and gives experience to the students to participate actively in English class. On the other hand, the students who have low level of risk-taking usually has low attitude in joining the teaching and learning process. They tend to keep silent and have no willingness to try something new relating to the target language. They will be passive in doing the activity and tend to depend on their friends and their teacher all the time in teaching and learning process. They are unwilling to use complex and difficult linguistics elements. Therefore, it can be concluded that the students with high level of risk-taking have better writing skill than the students with low level of risk-taking.

Thirdly, the use of TPS encourages students to write more. It helps the students to develop conceptual understanding of a topic because they discuss it with their friends in pair. It makes them feel free to talk about everything they want deal with the topic. By doing that activity their ability to filter information, draw conclusion and consider point of view will be developed. TPS activities give opportunity to the students to have writing activity in pair actively and independently. They have more chances to develop themselves in constructing writing with their pairs. Hence, TPS is suitable for the students with high level of risk-taking. They have characteristics of active students who always take a risk of being wrong and take every opportunity they have to try something new. Students with high level of risk-taking feel comfortable in learning writing with TPS method since this method encourages them to develop their skill in pair freely. They have opportunity to share with friend and feel free to make mistakes since their friend will make correction and it makes them explore what they want to write. Therefore, TPS method is more effective for teaching students with high level of risk-taking.

On the other hand, DIM gives a few motivation and stimulation to the students because it just focuses in lecturing and drilling activities. DIM includes lecturing, didactic questioning, and explicit teaching, practicing and drilling, and demonstrating. It is highly structured and teacher directed. The teacher selects and directs the learning tasks. DIM is suitable for the students who have low level of risk-taking. Students with low level of risktaking are not actively involved during the activities. They do not want to appear foolish when they make mistakes. As result, they tend to keep silent during the lesson. They avoid taking a risk of being wrong and always wait for their teacher explanation and instruction. Moreover, they do not have tolerance of possible incorrectness or inexactitude in using the language. Hence, they feel more comfortable to be taught using DIM. Therefore, there is an interaction between methods used and the level of risk-taking of the students in teaching writing. TPS is more effective than DIM to teach writing to the students with high level of risk-taking. Meanwhile, DIM is more effective than TPS to teach writing to the students with low level of risk-taking. 


\section{CONCLUSION}

Based on the research finding described, some conclusions can be stated: 1) TPS is more effective than DIM to teach writing; 2) The students with high level of risk-taking have better writing skill than those with low level of risk-taking; 3) There is an interaction between teaching methods and the students' level of risk-taking to teach writing. In teaching writing, teachers need to try many methods to improve the students' writing skill. One of the good methods to teach writing is TPS. This method is proved to be more effective than DIM in teaching writing. To make TPS working properly, it needs to be applied properly in the teaching and learning process. The procedures of TPS are think, pair and share. However, the result of the method applied is also affected by the students' characteristics. As proved by the research conducted by some researchers, TPS method is more suitable for the students with high level of risk-taking. Meanwhile, DIM is more suitable for the students with low level of risktaking. Finally, this research is expected to be useful for the students, teachers, and future researchers. Therefore, some suggestions are listed as follows: 1) TPS is strongly recommended for the teachers to teach writing; 2) the teachers have to consider about the students' level of risk-taking to determine the suitable method used to teach them; 3) The students are expected to be more active in teaching and learning process in order to develop their writing skill; 4) The students need to adjust themselves to the method used by the teacher; 5) The future researcher may use the result of this research as a starting point to conduct another research.

\section{REFERENCES}

Alan, C. (2003). The linguistic learning. New York: Viction Graphics, Inc.

Arends, R. (1997). Classroom instruction and management. Boston: McGraw Hill

Bang, Y. (1999). Factors affecting Korean students' risk-taking behavior in ESL classroom. Dissertation. Ohio University. Ohio. Retrieved from http://etd.ohiolink.edu/view.cgi?acc_num=osu124 3019322.

Binder, C., \& Watkins, C. L. (1990). Precision teaching and direct instruction: Measurably superior instructional technology in schools. Performance Improvement Quarterly, 3, 74-96.

Brown, H. D. (2001). Teaching by principles: An interactive approach to language Pedagogy. San Francisco: Pearson Education, Inc.

Caroline, C. (2003). Teaching academic writing. London: Centre of Language and Communication, Routledge, Falmer.

Graham, S., \& Perrin. (2007). Writing next effective strategy to improve writing of adolescent in middle and high school. New York: Carnegie Corporation of New York.

Luft, S. (2007). Language classroom risk- taking behavior in a performed culture based program. Thesis, School of the Ohio State University. Retrieved on August, 2012 from http://etd.ohiolink.eduview,cgiacc.num = osul 1229701363.

Lyman, F. (2005). Description of exemplary techniques and methods. London: Prentice Hall. 
Ningtyas Orilina Argawati \& Lilis Suryani

Teaching writing using think-pair-share viewed from students' level of risk-taking 